\title{
DIMENSI MISTIK DALAM EVENT PACU JALUR
}

\author{
Hasbullah \\ Universitas Islam Negeri Sultan Syarif Kasim Riau, Indonesia \\ hasbullah@uin-suska.ac.id
}

\begin{abstract}
Abstrak
Penelitian ini bertujuan untuk menjelaskn dimensi mistik yang terdapat dalam event pacu jalur. Pacu jalur tidak hanya melibatkan unsur fisik, namun juga hal-hal yang bersifat mistik. Dukun merupakan tokob utama berkaitan dengan jalur. Perannya terlihat dengan jelas mulai dari menetapkan lokasi pencarian kayu, memilih kayu yang akan dibuat jalur, pemberian nama jalur, sampai pada pacuan berlangsung. Oleh karena itu, perlu dilakukan kajian yang mendalam tentang dimensi mistik yang terdapat dalam event pacu jalur. Kajian ini menggunakan metode kualitatif. Metode ini dipandang tepat karena data-data yang diperlukan semuanya bersifat kata-kata atau penjelasan. Teknik. pengumpulan data yang digunakan adalah observasi, wawancara, dan dokumentasi. Informasi yang berkaitan dengan kajian ini didapatkan dari informan kunci, yaitu: dukun jalur, tukang jalur, anak pacu, pengurus jalur, tokoh agama, tokob adat, dan tokoh masyarakat. Hasil penelitian menemukan bahwa dimensi mistik hampir terdapat pada setiap proses dalam pacu jalur. Bertahannya hal-hal yang bersifat mistik dalam event pacu jalur dikarenakan masyarakat mempercayai bahwa hal tersebut tersebut mempunyai kekuatan dan berpengaruh dalam memenangkan perlombaan.
\end{abstract}

Kata kunci: Pacu Jalur, Dukun, Mistik, dan Kuantan Singingi.

\section{PENDAHULUAN}

Pacu jalur merupakan event tahunan yang menjadi kebanggaan masyarakat Kuantan Singingi. Event ini bukan tidak hanya bertaraf lokal, tetapi juga termasuk event yang bertaraf nasional (Suwardi, 2007: 126). Pelaksanaan event pacu jalur sebagai festival tahunan terbesar untuk masyarakat Kabupaten Kuantan Singingi, khususnya pada ibu kota kabupatennya, yaitu Teluk Kuantan dan daerah yang berada di sepanjang Sungai Kuantan. Pada awalnya, pacu jalur diadakan sekali setahun dalam rangka memperingati hari-hari besar umat Islam seperti Hari Raya Idul Fitri, Idul Adha, Maulid Nabi, ataupun peringatan tahun baru Hijriah. Selanjutnya, pada masa pemerintahan Belanda event ini dilaksanakan untuk memperingati hari lahir Ratu Wihelmina (Ratu Belanda) yang biasanya dilaksanakan pada bulan November. Setelah Indonesia merdeka, event ini ditujukan untuk merayakan Hari Ulang Tahun Kemerdekaan Republik Indonesia (Suwardi, 2007: 126-127). Peserta event ini biasanya berasal dari kecamatan se-Kabupaten Kuantan Singingi, kabupaten tetangga, bahkan juga pernah diikuti oleh negara-negara tetangga seperti Malaysia, Singapura, dan Thailand.

Pacu jalur merupakan bagian dari kehidupan masyarakat Kabupaten Kuantan Singingi, dan didukung sepenuhnya oleh masyarakat, baik secara moril maupun materil. Oleh karena itu, tidak heran jika pada waktu pertandingan masyarakat datang berbondong-bondong menyaksikan pertandingan. Bagi masyarakat yang jalurnya masuk final, maka dapat dikatakan kampung akan kosong pada hari itu, karena mereka pergi untuk menyaksikan perlombaan dan memberi dukungan kepada anak pacu. Pacu jalur bukanlah event yang hanya menampilkan perlombaaan, tetapi di dalam memiliki gengsi tersendiri, sehingga setiap kelompok berusaha untuk memenangkan. Hal ini tidak bisa dilihat dari hadiah yang disediakan oleh panitia, karena hadiah yang diterima oleh pemenang tidak sesuai dengan biaya yang mereka keluarkan untuk persiapan mengikuti pertandingan.

Event pacu jalur bukanlah event yang semata-mata terkait dengan kekuatan fisik untuk mengayuh jalur tersebut, tetapi terdapat unsur-unsur lain yang berkaitan dengan magis mistik. Secara kasat mata, event 
ini hanya merupakan kegiatan fisik yang melibatkan kekuatan tenaga, strategi, kekompakan, dan semangat anak pacu, di sampai kualitas jalur itu sendiri. Namun, di sebalik itu semua ada kepercayaan di tengah masyarakat bahwa untuk memenangkan pacu jalur juga melibatkan hal-hal yang bersifat magis dan mistik. Jadi, dapat dikatakan bahwa pacu jalur adalah wujud dari kreasi budaya dan karya seni yang merupakan perpaduan antara unsur olahraga (fisik), seni, dan magis, dan mistik. Oleh karena itu, masyarakat percaya bahwa jalur yang akan memenangkan perlombaan adalah jalur yang memiliki perpaduan sempurna unsur-unsur yang sudah disebutkan di atas.

Kajian tentang pacu jalur sudah banyak dilakukan oleh para peneliti, di antaranya kajian yang berkaitan dengan pariwisata yang dilakukan oleh Dylla Novrilasari, Zulfan Saam, dan Aras Mulyadi (2014), kajian yang mengaitkan pacu jalur dengan ekonomi masyarakat di antaranya dilakukan oleh Andri Yulis (2017); kajian yang menjelaskan unsur seni yang terdapat dalam pacu jalur dilakukan oleh Henny Hertati dan Achmad Hufad (2010); dan kajian yang menjelaskan jalur yang dihubungkan dengan nilai-nilai magis dilakukan oleh Silawati dan Aslati (2015), dan R. Saleh (2017). Kajian ini berbeda dengan kajian-kajian sebelumnya, kajian ini akan melihat unsur mistik yang terdapat dalam pacu jalur, mulai dari mencari kayu jalur sampai perlombaan berlangsung.

\section{METODE}

Penelitian ini menggunakan metode kualitatif. Metode ini dipilih karena dapat menjelaskan fenomena yang dikaji. Kajian ini berkaitan dengan hal-hal yang bersifat penjelasan dan sama sekali tidak memerlukan angka-angka. Fenomena penelitian akan dijelaskan secara deskriptif, sehingga akan terlihat dengan jelas keterkaitan antara berbagai berbagai gejala, baik eksternal maupun internal yang terdapat dalam event Pacu Jalur di Kabupaten Kuantan Singingi. Penelitian ini mengambil lokasi di Kabupaten Kuantan Singingi. Pemilihan lokasi berdasarkan terdapat fenomena yang akan dikaji. Data pokok (data primer) dalam penelitian ini berkaitan dengan fenomena objek penelitian yaitu dimensi mistik dalam event Pacu Jalur, meliputi: mistik dalam pencarian dan pemilihan kayu sampai menjadi jalur, pelaksanaan perlombaan, tempat dan waktu, media (alat-alat) yang digunakan, orang-orang yang terlibat, serta data-data lain yang dipandang terkait dengan penelitian ini. Teknik pengumpulan data yang digunakan adalah observasi, wawancara, dan dokumentasi. Untuk mendapatkan data, peneliti menetapkan informan kunci, yaitu orang yang dapat memberikan informasi secara mendalam dan rinci tentang kebudayaan dan tradisi yang terdapat di Kabupaten Kuantan Singingi, dan orang yang mampu memberikan informasi secara mendalam tentang Pacu Jalur yang terdapat di Kabupaten Kuantan Singingi. Informan terdiri dari dukun jalur, tukang jalur, pengurus jalur, anak pacu, tokoh masyarakat, tokoh agama, dan tokoh adat. Kegiatan analisis data dilakukan mengikuti proses antara lain, reduksi data (sortir data), penyajian data, dan menarik kesimpulan berdasarkan hasil reduksi dan penyajian data yang telah dilakukan sebelumnya. Pengolahan data atau analisis deskriptif (descriptive analysis) mengandung pengertian sebagai usaha untuk menyederhanakan dan sekaligus menjelaskan bagian dari keseluruhan data melalui langkahlangkah klasifikasi sehingga tersusun suatu rangkaian deskripsi yang sistematis dan akurat. Untuk mendapatkan informasi yang betul-betul akurat, maka dilakukan cek silang (cross cek) melalui teknik triangulasi terhadap setiap informasi yang diperoleh, baik informasi yang diperoleh melalui wawancara mendalam (in depth interview) maupun informasi yang diperoleh melalui observasi.

\section{HASIL DAN PEMBAHASAN}

\section{Mistik dalam Proses Mencari dan Menebang Kayu Jalur}

Pembuatan jalur melalui beberapa tahapan. Tahapan tersebut memakan waktu yang cukup panjang hingga sebuah jalur yang bisa dipacukan di gelanggang. Hal tersebut berkaitan dengan tenaga, biaya, dan lain-lain. 
Segala sesuatunya harus diperhitungkan secermat mungkin agar semua tahapan yang akan dilalui dalam proses pembuatan jalur berjalan dengan lancar. Oleh karena itu, proses pembuatan jalur hingga dapat dipacukan di gelanggang melibatkan berbagai unsur yang terdapat di tengah masyarakat. Setiap unsur tersebut memainkan peranan tersendiri hingga menjadi satu kesatuan yang utuh.

Tahapan yang paling awal dalam pembuatan jalur adalah pembentikan pengurus jalur (dahulunya disebut partuo). Pengurus ini bertugas mengurus segala sesuatu yang diperlukan dalam pembuatan jalur. Pengurus jalur pada suatu desa tidak harus ditunjuk setiap tahun, namun apabila ada tuntutan dari masyarakat agar pengurus diganti barulah diadakan musyawarah untuk menggantinya. Jumlah pengurus tidak ditentukan, semuanya ditunjuk ketika rapat yang dilakukn oleh suatu banjar atau kampung (Wawancara dengan Ajasmi [Tokoh Masyarakat], 5 Oktober 2016).

Banyak hal yang diputuskan dalam rapat ini, di antaranya waktu yang tepat untuk mencari kayu, daerah atau hutan mana yang cocok untuk dijadikan tempat mencari kayu, dan waktu yang tepat untuk berangkat. Hal yang paling penting diputuskan dalam rapat tersebut adalah siapa yang akan menjadi dukun jalur. Karena Menurut kepercayaan masyarakat setempat, setiap tempat atau benda senantiasa dikuasai oleh kekuatan gaib (Wawancara dengan Muhammad Judin [Dukun Jalur], 6 Oktober 2016). Kepercayaan seperti ini juga ditemukan di berbagai tempat di Kabupaten Kuantan Singingi. Masyarakat percaya bahwa di berbagai tempat ada "penunggunya", seperti jin, setan, dan makhlukmakhluk lainnya (Hasbullah, 2014: 157). Mereka percaya bahwa makhluk tersebut ada yang baik dan ada pula yang jahat. Dengan demikian, peran dukun sangatlah dibutuhkan karena ia dianggap mengetahui keadaan tersebut (UU. Hamidy, 2005: 41; Wawancara, Muhammad Judin [Dukun Jalur], 6 Oktober 2016).

Setelah semua unsur masyarakat di dalam pengurus jalur mendapat kata sepakat, langkah selanjutnya adalah mencari kayu jalur ke dalam hutan. Sebelum mencari kayu ke hutan, dukun terlebih dahulu melakukan upacara khusus di rumahnya atau di rumah kepala desa. Ada dua macam upacara yang biasa dilakukan dukun, yaitu upacara babalian atau upacara batonuang (diramal). Upacara babalian adalah suatu upacara tari-tarian yang dilakukan oleh sang dukun dengan iringan musik rebab (sejenis alat gesek). ${ }^{1}$ Sedangkan upacara batonuang adalah suatu upacara khusus yang dilakukan oleh dukun untuk mencari kayu dengan cara menggunakan kekuatan magis dan mantra-mantra. Melalui cara tersebut dukun dapat menemukan tempat atau lokasi hutan yang cocok untuk mencari kayu (Syaiful Bakri, 2012: 21). Selanjutnya dukun menetapkan waktu yang tepat untuk berangkat mencari kayu jalur dengan cara mencari pelangkahan (pelangkah). ${ }^{2}$ Apabila dukun telah menetapkan pelangkahannya, maka semua anggota yang ikut dalam mencari kayu harus mengikuti semua perintah dukun, tidak boleh ada yang mengingkarinya.

Kayu yang dijadikan jalur adalah kayu yang tahan air dan tidak mudah pecah kalau

${ }^{1}$ Dalam masyarakat tradisional, musik (salah satunya rebab) sering digunakan untuk mengiringi berbagai ritual, termasuk ritual pengobatan togak balian di Kabupan Kuantan Singingi. Musik ini berfungsi untuk mengiringi dukun dalam menari dan juga berkomunikasi dengan makhluk halus (lihat, Hasbullah, 2014).

${ }^{2}$ Pelangkah dalam masyarakat Melayu adalah istilah yang digunakan untuk memulai suatu perjalanan dengan menghitung hari dan waktu yang tepat. Pelangkah yang tepat akan menghasil kesuksesan, sedangkan pelangkah yang salah akan menghasilkan kegagalan. Dalam konteks pencarian kayu jalur, ada beberapa cara dukun menetapkan pelangkah, antara lain dengan cara berkomunikasi dengan makhluk halus dan selanjutnya akan disampaikan dalam mimpi sang dukun; dan ada juga dengan cara menghitung waktu, yaitu menetapkan hari dan jam akan berangkat. Penghitungan waktu yang digunakan adalah bulan di atas atau menurut hitungan bulan Hijriyah. 
dibuat menjadi jalur. Di samping itu yang paling penting adalah kayu tersebut berdiameter besar dan panjang. Selain syarat fisik tersebut, kayu yang digunakan untuk jalur adalah kayu yang dipandang memiliki ruh (mambang). Mambang yang menghuni kayu tersebut berguna dalam pacu jalur di gelanggang. Oleh karena itu, kayu yang tidak memiliki mambang, maka jalurnya tidak akan pernah menang. Kepercayaan mistik ini merupakan warisan paham animisme dan dinamisme yang mempercayai bahwa setiap benda memiliki penunggu atau penghuni, termasuk pohon ataun kayu. Dalam hal ini dukun memiliki peran penting untuk mengendalikan mambang yang ada pada kayu tersebut. Jika mambang yang ada pada kayu tersebut dapat dijinakkan, maka kayu tersebut dianggap mempunyai tuah. Menurut keyakinan dukun, mambang tersebut akan terus mengikuti kayu itu kemanapun kayu itu dibawa. Oleh karena itulah dukun jalur jarang diganti oleh pengurus jalur, karena duku yang memantrai kayu jalur mulai dari menebang juga dianggap mampu "berkomunikasi" dan "memelihara" hubungan dengan mambang yang terdapat pada kayu tersebut (Wawancara, Susi Yanti [Dukun Jalur], 8 Oktober 2016).

Menurut UU. Hamidy (2005: 23), dukun yang mendampingi pengurus jalur dalam usaha mencari kayu jalur jumlah bisa lebih dari satu orang. Dalam proses pencarian kayu, dukun menentukan apakah kayu yang akan ditebang tersebut baik atau tidak. Jika dibuatkan jalur apakah kayu tersebut dapat menghasilkan jalur yang laju atau tidak, di samping itu juga apakah kayu tersebut dapat bertahan lama. Salah satu cara sang dukun untuk mengetahui kualitas kayu adalah dengan cara dikoresi (dilihat semua aspek-aspek magisnya) dan dukunlah yang tahu akan hal tersebut (Wawancara, Susi Yanti [Dukun Jalur], 8 Oktober 2016). Ada beberapa tanda bahwa kayu itu mengandung tuah, baik secara fisik maupun setelah kayu itu ditebang, yaitu: (1) Selendang akar, yaitu terdapat kayu kecil yang tumbuh di dekat kayu besar yang akan ditebang dan dahannya melilit kayu besar tersebut. Di samping itu, kualitas kayu kecil tersebut juga dilihat apakah termasuk jenis kayu yang keras atau yang lunak. Jika jenis kayu yang tumbuh di dekatnya termasuk kayu yang keras, maka kualitas kayu yang akan ditebang tersebut tidak diragukan, (2) Melanggar tunggul, yaitu jatuhnya atau tumbangnya agak jauh dari tunggulnya, dan (3) Melompati sungai, yaitu ada bagian kayu setelah tumbang menyeberangi sungai.

Ciri-ciri kayu yang tuah kayu yang banyak dihinggapi oleh binatang berbisa/beracun, seperti kalajengking, ular, dan sebagainya. Sebab kayu yang semacam itu adalah kayu yang "berbahaya" dan biasanya akan laju bila dijadikan jalur dibandingkan dengan kayu yang yang tidak banyak dihinggapi oleh binatang berbisa/beracun yang ditakuti oleh manusia (Wawancara, Muhammad Judin [Dukun Jalur], 6 Oktober 2016). Dikatakan memiliki tuah karena mambang yang menghuni kayu tersebut mudah dijinakkan oleh dukun. Dengan demikian, tuah merupakan bagian mistik yang terdapat pada kayu dan tidak bisa dijelaskan secara rasional, melainkan hanyalah sebuah kepercayaan.

Untuk mencari satu kayu jalur yang sesuai dengan keinginan, terkadang masyarakat harus berulang kali ke hutan. Karena diyakini, kayu tersebut kadang-kadang bisa dilihat oleh manusia dan juga tidak, hal ini dipercayai karena kayu tersebut memiliki ada penunggu (Wawancara, Nurlis [Dukun Jalur], 7 Oktober 2016). Setelah menemukan kayu dan disepakati oleh semua pihak, maka kayu itu harus diberi tanda. Sebelum ditandai dukun akan membakar kemenyan tepat pada pungko (pangkal) pohon tersebut. Asap dari kemenyan yang dibakar diyakini dapat mengusir hantu, jin, dan makhlus halus yang berada di sekitar pohon, dan yang paling penting gunanya adalah untuk manyojuakan (menyejukkan) pohon tersebut (Wawancara, dukun jalur, 3 - 8 Oktober 2016).

Setelah disepakati hari keberangkatan dengan perhitungan langkah-langkah dari sang dukun (pelangkah), maka mereka akan berangkat menuju hutan dengan perlengkapan yang diperlukan untuk penebangan. Sebelum penebangan dimulai, dukun terlebih dahulu melakukan ritual 
khusus yang disebut menyemah, yaitu menyerahkan semah (sesajen) kepada mambang yang diyakini sebagai penunggu kayu tersebut. Upacara ini dimaksudkan untuk menghindari hal-hal yang tidak diinginkan seperti menimbulkan bencana, baik bagi tukang tebang maupun orang-orang yang menyaksikan acara penebangan kayu (Wawancara, dukun jalur, $3-8$ Oktober 2016).

Sebelum kayu jalur ditebang, terlebih dahulu melakukan ritual untuk membangunan mambang kayu tersebut. Upacara ini dipimpin oleh dukun dengan beberapa rangkaian kegiatan seperti penyembelihan ayam, pembakaran kemenyan, tepung tawar, dan sebagainya. Ayam disembelih langusng oleh dukun, dan ayam digunakan dalam ritual ini biasanya berwarna hitam jamui (putih suci), atau biriang kuniang, atau jalak. Kemenyan dibakar pada sekeliling pohon tersebut dan disirami tepung tawar sambil membaca mantra (Hasbullah, Ashori, \& al-Masri, 2016: 35).

Kayu yang ditebang diharapkan tumbang ke arah timur, karena $\mathrm{k}$ matahari juga terbit sebelah timur, sebagai tanda cahaya dan kekuatan. Hal ini dimaksudkan agar kayu tersebut mempunyai kekuatan serta semangat seperti terangnya cahaya matahari yang terbit, menandakan akan ada tandatanda kehidupan dan optimisme. Merebahkan ke arah Matahari terbenam tidak dibolehkan, karena arah matahari akan tenggelam atau arah matahari "mati" dan tidak bercahaya lagi, tentu ini menandakan tidak ada kekuatan di dalamnya. Dengan demikian, menumbangkan kayu ke arah barat merupakan pantangan dalam penebangan kayu jalur. Selain itu, juga pantang membuang air kecil di sekitar kayu jalur yang akan ditebang (kalau mau buang air minimal harus berjarak 50 meter dari kayu), dan tidak boleh bercakap-cakap kotor, seperti memaki, sumpah serapah, dan sejenisnya.

Mistik dalam Memberi Nama Jalur

Setelah jalur siap dibuat, pengurus dan dukun jalur memikirkan nama yang tepat untuk jalur mereka. Pemberian nama jalur tidak bisa dilakukan semaunya saja, karena nama suatu jalur megandung makna tertentu.
Rapat pemberian nama jalur biasanya berjalan alot, karena terjadi silang pendapat antara peserta rapat. Saleh (2013: 49) menjelaskan bahwa nama jalur sangat penting, bahkan tidak jarang nama jalur lebih dikenal dibandingkan nama desa asal jalur tersebut. Nama jalur ditulis di bagian haluan jalur, di bagian timbo ruang (di tengah) akan ditulis nama desa, dan di bagian belakang akan ditulis tanggal, bulan, dan tahun pembuatannya.

Nama jalur sering mengandung kekuatan mistik, karena dalam nama tersebut tersirat kekuatan magis yang ada di dalamnya. Paling tida ada tiga cara dalam memberi nama jalur, yaitu: (1) jalur yang diberi nama oleh masyarakat berdasarkan hasil rapat, (2) jalur yang diberi nama oleh dukun, dan (3) jalur yang diberi nama berdasarkan legendalegenda geografis desa dan juga tempat kayu ditebang. Dengan demikian, pemberian nama suatu jalur harus ada kesepakatan antara masyarakat, pengurus jalur, dan dukun jalur. Setiap nama jalur tersebut mengandung makna tanda (sign) yang dalam teori semiotika merupakan salah satu komponen pokok. Dengan demikian, tanda merupakan sesuatu yang mengandung makna. Jalur yang diberi nama tertentu diharapkan memiliki kekuatan atau kemampuan seperti yang memiliki nama tersebut. Hal ini sesuai dengan yang dinyatakan oleh Saussure, seperti dikutip oleh Yasraf Amir Piliang (2003: 175) bahwa sebuah tanda terdiri dari penanda (signifier) dan petanda (signified). Penanda mengacu pada benda yang dirujuk, citraan atau kesan mental dari sesuatu yang bersifat verbal atau visual, seperti suara, tulisan, atau benda. Sedangkan petanda adalah makna yang tersirat, konsep abstrak, atau makna yang dihasilkan oleh tanda.

Ada empat kategori yang harus dipertimbangkan oleh oleh pengurus, masyarakat, dan dukun jalur dalam pemberian nama suatu jalur, yaitu:

1. Berdasarkan nama binatang yang berbisa dan buas.

Banyak sekali nama jalur dengan nama binatang berbisa/beracun. Seperti yang sudah dijelaskan sebelumnya bahwa binatang berbisa/beracun yang terdapat pada kayu 
jalur saat penebangan merupakan salah satu tanda bahwa kayu jalur tersebut memiliki sakti atau tuah. Tujuan memberi nama dengan nama binatang yang "membahayakan" adalah agar jalur tersebut kuat, laju, dan juga buas, sehingga lawanlawannya dengan mudah dikalahkan. Jalurjalur yang namanya berdasarkan nama binatang berbisa antara lain: (1) Singa Kuantan, (2) Mantiko Limbek Putiah, (3) Gajah Tunggal Bukik Tigo, (4) Sembaran Olang Pulai, (5) Harimau Paing Tuah Nagori, (6) Kalojengking Tigo Jumbalang, (7) Siposan Rimbo, (8) Merpati Kuantan, (9) Nago Sati, (10) Olang Barantai, (11) Elang Sati, (12) Harimau Kompe, (13) Ular Lidi Sipancuang Umbuik, (14) Kibasan Nago Liar, dan lainlain. Biasanya nama seperti ini diberikan oleh dukun berdasarkan binatang yang ditemukan pada waktu penebangan kayu jalur di hutan. Nama-nama ini juga bisa dipahami sebagai nama mambang yang menguasai jalur tersebut. Hal ini hanyalah dukun yang mengetahuinya, mambang apa yang menunggu kayu tersebut dan dijadikan alasan untuk nama jalur.

2. Berdasarkan nama tokoh yang melegenda pada suatu masyarakat

Dalam setiap masyarakat suatu desa di Kuantan Singingi ada tokoh-tokoh yang menjadi legenda bagi masyarakat tersebut, seperti tokoh raja, pendekar, dubalang, putra/putri, sutan, panglima, dan lain-lain. Untuk mengabadikan nama mereka, biasanya dibuatkanlah menjadi nama jalur. Biasanya nama tokoh tersebut berdasarkan cerita dan kisah di masyarakat di mana tokoh-tokoh tersebut pada masanya terkenal dengan kesaktiannya. Di antara nama tokoh yang dijadikan nama jalur antara lain: (1) Keramat Jubah Merah, (2) Pendekar Sati Rantau Kuantan, (3) Pendekar Hulu Bukik Tabandang, (4) Datuak Lebar Dado, (5) Pendekar Panjang Bukit Siguntur, (6) Dubalang Rajo Mangkuto Alam, (7) Dubalang Sati Harimau Kompe, (8) Keramat Sati Raja Cikuan, (9) Pangeran Hilir Rantau Kuantan, (10) Putri Mandi Mayang Terurai, (11) Putra Dewa Bukit Keramat, (12) Sutan Nan Garang, (13) Panglimo Sati, dan lainlain.
3. Berdasarkan tempat atau benda-benda angket

Tempat dan benda angker juga paling banyak dijadikan nama sebuah jalur setelah nama binatang buas dan berbisa. Dengan memberi nama jalur dengan nama-nama yang angker, sang dukun yakin bahwa jalur tersebut juga akan menjadi jalur yang angker dan ditakuti oleh lawan-lawannya. Hal ini berasal dari kepercayaan masyarakat bahwa tempat-tempat tersebut dikuasai oleh makhluk halus yang mempunyai kekuatan atau kesaktian yang dapat dimanfaatkan oleh manusia untuk membantu mereka dalam halhal tertentu. Nama jalur disesuaikan dengan tempat-tempat angker atau keramat yang ada pada suatu desa yang melegenda di tengah masyarakat, atau berasal dari hutan yang dianggap angker tempat kayu jalur diambul. Jalur-jalur yang memiliki nama-nama tersebut antara lain : (1) Kibasan Gajah Putiah, (2) Selendang Putri Danau Seroja, (3) Rawang Udang, (4) Sarijadi Gemetar Alam, dan lainlain.

4. Berdasarkan pemberi sponsor

Dewasa ini juga banyak jalur yang disponsori oleh lembaga atau perusahaan. Untuk mengabadikan nama sponsor atau yang membiayai jalur tersebut, maka dicarilah satu nama, baik berasal dari tokoh yang melegenda, binatang berbisa/beracun, maupu tempat angker/keramat dan digandeng dengan nama pemberi sponsor tersebut. Nama jalur tersebut merupakan gabungan antara nama yang dipilih dan nama sponsornya, di antara nama-nama jalur tersebut antara lain: (1) Linggar Jati RAPP, (2) Siguntuang Sati Riau Pos, (3) Garuda Putih RZ-MM, dan lain-lain.

\section{Mistik dan Ritual dalam Perlombaan}

Event pacu jalur di tepian narosa (arena perlombaan) merupakan puncak dari prosesi sebuah jalur. Di arena inilah sebuah jalur diuji tuahnya dan begitu juga dengan dukun yang memegangnya sejak awal. Tahapan awal dala event pacu jalur adalah pencabutan undi oleh para peserta pacu. Pencabutan ini merupakan cara untuk mengetahui kapan suatu jalur akan berpacu, dan dan jalur mana saja yang menjadi lawan. Dukun jalur sudah mulai memainkkan peranannya untuk menetapkan 
pelangkah kapan jalur yang dipegangnya akan berangkat menuju ke arena pacu. Pada malam sebelum berangkat dukun jalur melakukan pemotongan limau ${ }^{3}$ sebanyak 3 kali untuk mengetahui posisi jalur yang dipegangnya dan juga berupaya menghindari bertemu dengan jalur-jalur lawan yang dianggap tangguh pada putaran awal. Seorang dukun jalur sudah tahu jalur mana saja yang dianggap tangguh, dan karena itu ia bertugas untuk menghindari jalur yang dipegangnya bertemu dengan jalurjalur tersebut. Untuk itu seorang dukun jalur akan melakukan pemotongan limau sebanyak 3 kali. Adapun makna dari ritual pemotongan limau adalah sebagai berikut:

1. Potongan limau yang pertama merupakan simbol dari jalur lawan. Jika potongan limaunya tertelungkup berarti jalur lawan kalah. Namun, jika sebaliknya (tertelentang) berarti jalur lawan menang.

2. Potongan limau kedua merupakan simbol jalur milik dukun. Jika potongan limaunya tertelentang, berarti jalur milik mereka menang. Namun, jika sebaliknya (tertelungkup) berarti jalur milik mereka kalah.

3. Potongan limau yang ketiga tidak memiliki makna apa-apa, hanya melengkapkan sebuah ritual potong limau saja (Hasbullah, Ashori, \& al-Masri, 2016: 39).

Hal di atas menjelaskan bahwa seorang dukun jalur sebenarnya sudah mengetahui apa yang akan terjadi pada pertandingan besok. Hal ini diketahui oleh dukun jalur di saat ia melakukan pemotongan limau. Menurut pengakuan duku jalur, limau yang ia potong dan di tempatkan di dalam sebuah mangkok akan berjalan-jalan sebagai simbol

${ }^{3}$ Potongan limau merupakan suatu media yang penting dalam dunia perdukunan. Hampir semua dukun yang menekuni berbegai bidang selalu menggunakan limau untuk mengetahui sesuatu yang berkaitan dengan bidang mereka. Hal ini terlihat jelas seperti dalam pengobatan balian, di mana potongan limau digunakan untuk mengetahui apakah penyakit yang diderita oleh si pasien dapat disembuhkan atau tidak (lihat, Hasbullah, 2014). dari sebuah pacuan. Dalam mangkok tersebut limau potongan milik dukun (potongan kedua) saling kejar-kejaran limau potongan milik lawan (potongan pertama). Dengan melihat kondisi ini, seorang dukun harus mencari jalan untuk menghindari jalur-jalur lawan yang lebih kuat dengan cara mencari pelangkah. Dalam menetapkan pelangkah biasanya dukun jalur melakukan komunikasi dengan mambang yang menunggu jalur tersebut. Pelangkah tersebut berguna untuk mengelak turun bersamaan waktu atau dalam waktu yang sama dengan jalur lawan. Oleh karena itu, dukun harus mencari pelangkah untuk menurunkan jalur, dengan cara menetapkan waktu sedikit lebih cepat atau sedikit lebih lambat dari waktu pelangkah yang diambil jalur lawan. Selisih waktu turun antara jalur yang dipegang oleh seorang dukun dengan jalur lawan tidak perlu terlalu lama, cukup beberapa menit saja.

Kemampuan seorang dukun jalur amat diuji dalam mencari atau menetapkan pelangkah. Hal ini terlihat dengan jelas dari setiap tahapan prosesi jalur, mulai dari proses pencarian kayu, penebangan kayu, sampai pertandingan. Menurut keyakinan masyarakat, mereka pelangkah amat menentukan apakah jalur mereka menang atau kalah di gelanggang. Menurut penjelasan dukun jalur, ada dua cara dalam menetapkan waktu melangkah, yaitu: pertama, seorang dukun harus menghitung (menghisap seperti dalam ilmu falak) tanggal atau hari pertandingan dan menetapkan kapan waktu yang tepat. Metode ini menggunakan rumus tertentu dengan cara menambah, mengurang, dan membagi angka-angka yang terdapat dalam hitungan tersebut. Hitungan hari bulannya kepada bulan yang di atas atau penanggalan hijriyah, dan bukan kalendar atau penanggalan masehi. Metode ini sudah tidak begitu banyak dikuasai oleh dukun. Kedua, dukun jalur bertanya kepada mambang yang menunggu jalur tersebut tentang waktu yang tepat untuk melangkah. Dengan kata lain, metode dilakukan melalui konsultasi dukun jalur dengan dengan mambang yang menunggu jalur (Wawancara, dukun jalur, 3 8 Oktober 2016). 
Sebuah jalur bisa saja mempunyai dukun lebih satu. Jika satu jalur hanya memiliki satu orang dukun, berarti dukun tersebut harus mengurus secara keseluruhan yang berkaitan dengan jalur. $\mathrm{Hal}$ ini merupakan merupakan pekerjaan yang amat berat bagi seorang dukun, karena dalam pacu jalur banyak hal yang terkait dan perlu diurus. Oleh karena itu, biasanya sebuah jalur mempunyai lebih dari satu orang dukun, dan setiap dukun memiliki kewajiban masingmasing. Meskipun demikian, sebuah jalur dikepalai oleh seorang dukun atau merupakan dukun utamanya. Paling tidak ada hal yang diurus oleh dukun jalur, yaitu yang berkaitan dengan jalur, tanah, dan air. Masing-masing dari mereka mempunyai tanggung jawab sendiri-sendiri; dukun jalur harus mengurus mambang yang terdapat di jalur; dukun tanah harus mengurus yang berkaitan sewaktu jalur masih di darat; dan dukun air harus mengurus hantu air di saat berlangsungnya pacu jalur di arena pacu. Mereka meyakini bahwa jika makhluk-makhluk gaib atau halus yang terdapat pada tempat tersebut tidak diurus, maka ia akan mengganggu jalannya atau melajunya jalur tersebut atau juga bisa mengganggu anak pacu. Hal ini juga untuk menghindari pemanfaatan hantu air oleh dukun lain atau jalur lawan untuk menghalang-halangi lajunya jalur milik mereka. Itulah alasan mengapa sebelum jalur dilepas terlebih dahulu perlu dilakukan ritual terhadap jalur untuk menghindari mahkluk halus yang ada di air.

Ritual tidak hanya dilakukan oleh dukun jalur terhadap jalur, melainkan juga untuk anak pacu dengan tujuan untuk menjaga diri anak pacu agar selamat dan memenangkan pertandingan. Ritualnya dipimpin langsung oleh sang dukun dan dibantu para pengurus jalur. Proses ritual dimulai dengan meminta anak pacu duduk sambil berbaris, kemudian mereka diberi sesuatu oleh dukun yang berguna sebagai obat dan kekuatan bagi anak pacu. Biasanya yang diberikan kepada anak pacu berbentuk benda, seperti bonbon, beras, dan lain-lain untuk dimakan. Setelah itu, anak pacu dikelilingi oleh sang dukun sambil menyiramkan sedikit demi sedikit air tepung tawar kepada anak pacu, kemudian masingmasing anak pacu membaca doa dalam hati.

Setelah ritual di atas selesai, sang dukun memerintahkan untuk mulai mengisi jalur. Menurut sang dukun, jalur kita harus diisi terlebih dahulu daripada jalur lawan. Mengisi jalur tidak boleh lambat-lambat, lebih cepat diisi lebih baik. Semua anak pacu harus mentaati perintah sang dukun, jika sang dukun memerintahkan berangkat ke panjang start, maka cepatlah berangkan dan jangan diperlambat. Selama berada di dalam jalur, dukun juga memesankan kepada anak pacu untuk membaca ayat-ayat al-Qur'an (khususnya ayat-ayat pendek) menjelang pertandingan berlangsung. Dalam proses mengisi jalur, orang yang pertama masuk adalah tukang onjai, kemudian tukang timbo ruang, dan tukang tari, dan barulah anak pacuan sebagai pendayung.

Setelah semua anak pacu mengisi jalurnya, sebelum jalur tersebut didayung terlebih dahulu sang dukun akan memegang haluan jalur untuk mencari langkah kapan harus didayung. Biasanya sang dukun memegang haluannya antara 2 hingga 15 menit. Sang dukun menemukan langkahnya dari denyut sang haluan jalur. Ada semacam kontak antara sang dukun dengan mambang yang ada di dalam jalur. Kalau kontak tersebut belum muncul, jalur jangan dilepas, tahan saja sampai kontak dan bisik-bisik itu sampai ada. Tidak ada kepastian tentang langkah ini, karena dukun hanya mengikutkan gerak hati yang dipercayai merupakan perintah dari mambang jalur.

Setelah anak pacu berada di dalam jalur, juga terdapat beberapa pantang larang atau hal-hal yang tidak boleh dilakukan oleh anak pacu. Pantang larang ini harus dijaga oleh semua anak pacu, karena diyakini jika pantang larang ini dilanggar, maka jalur mereka akan kalah. Di antara pantang larang tersebut adalah: (1) tidak boleh buang air kecil di dalam jalur, (2) tidak boleh meludah ke arah jalur lawan, (3) tidak boleh berkata kotor, dan (4) tidak boleh mandi ke arah jalur lawan. Selama berada di dalam jalur, menjelang pertandingan berlangsung, anak pacu diminta untuk tetap fokus dan konsentrasi serta berdoa kepada Allah atau 
membaca ayat-ayat pendek agar jiwa mereka menjadi tenang dan tidak gugup.

Untuk melepaskan jalur ke panjang start, dukun menunggu kontak batin atau gerak hati. Hal ini juga didapat dari bisikan mambang yang menunggu jalur tersebut. Setelah selesai berpacu dan mendengarkan keputusan dewan hakim, maka sang dukun akan menanti jalur tersebur di tambatan kajang (Semacam tempat parkir jalur). Jika sewaktu berpacu mambang jalur dilepas, maka sekarang mambang juga ditarik kembali ke dalam jalur. Seperti yang sudah disebutkan sebelumnya bahwa mambang jalur berasal dari mambang yang menghuni kayu sebelum dibuat jalur. Melalui negosiasi dukun, mambang tersebut tetap dibawa kemana saja kayu tersebut berada. Dengan demikian, jalur merupakan rumah baru bagi mambang setelah rumah lamanya (pohon) ditebang dan diubah menjadi jalur. Hal ini merupakan kontrak atau perjanjian antara dukun dengan mambang di saat melakukan penebangan kayu.

Dari penjelasan para dukun jalur, kelihatannya tidak ada kesepakatan tentang keterlibatan mambang pada saat pacu jalur berlangsung. Ada yang mengatakan bahwa mambang tersebut terlibat langsung, dan ada juga yang mengatakan tidak terlibat langsung. Demikian juga halnya dengan jumlah mambang yang terdapat di jalur tersebut, ada yang mengatakan satu, dua, bahkan ada yang mengatakan terdapat tiga mambang dalam satu jalur. Terdapat perbedaan jumlah dikarenakan seorang dukun jalur dapat mengisi jalur tersebut dengan mambang lain dengan cara mengundang mambang tertentu yang terdapat di kampung tersebut. Bagi dukun jalur yang mengatakan mambang terlibat langsung dalam pacuan menjelaskan bahwa setiap mambang memiliki tugas tertentu selama pacun berlangsung. Sebagai contoh, mambang tersebut memiliki posisi tertentu di dalam jalur, ada yang di depan, di tengah, dan di belakang. Mambang yang berada di posisi depan bernama si unui, yang di tengah bernama si majana, dan di belakang bernama si majani; dukun yang lain menyebutnya dengan nama yang berbeda, misal; mambang di depan bernama si rongguik, yang di tengah bernama si rontak, dan di belakang bernama si mambang daban (Wawancara, Susi Yanti dan Omu [dukun jalur], 7-8 Oktober 2016). Oleh karena itu, sebelum pertandingan berlangsung dukun harus memastikan bahwa ketiga mambang tersebut berada di dalam jalur. Jika salah satu di antara mereka tidak terdapat di dalam jalur, maka sang dukun harus memanggilnya untuk datang dan menyatakan bahwa jalur kita akan segera berpacu. Untuk memanggil mambang tersebut, dukun menggunakan kakok tuo yang dahulu diambil saat penebangan kayu. Itulah sebabnya seorang dukun selalu menyimpan kakok tua tersebut yang dapat digunakan pada saat diperlukan.

Sedangkan dukun lain (Wawancara, Anisman dan Thamrin [dukun jalur], 4-5 Oktober 2016) menyatakan bahwa pada satu jalur hanya terdapat satu mambang dan mambang tersebut tidak terlibat langsung dalam pacuan. Di samping itu, mambang tersebut juga tidak terdapat dalam jalur melainkan berada di gelanggang penonton bersama masyarakat atau kembali ke tempatnya. Mambang sudah mengurus segala sesuatu syang berkaitan dengan pertandingan sebelum pertandingan atau pacuan berlangsung.

\section{PENUTUP}

Jalur merupakan wujud kebudayaan bagi masyarakat Kuantan Singingi yang diwariskan secara turun temurun dan makna tersendiri, baik sebagai diri pribadi maupun sebagai warga kampung. Maka tidak heran jika berkembang pandangan di tengah-tengah masyarakat bahwa tidak sempurna suatu kampung jika warganya tidak mempunyai jalur. Jalur merupakan perpaduan hasil karya budaya yang memperlihatkan kreativitas, imaginasi, dan nilai estetik.

Dimensi mistik begitu kental dalam event pacu jalur. Hal ini terlihat dengan jelas dari proses pencarian kayu, penebangan, pemberian nama jalur, sampai pertandingan berlangsung.Meskipun secara zahiriah event ini memperlihatkan aktivitas fisik, namun di sebalik itu semua sarat dengan hal-hal yang mistik. Masyarakat mempercayai bahwa jalur 
tidak bisa dilepaskan dari keyakinan yang bersifat mistik, seperti kepercayaan kepada adanya penunggu pada pohon, kepercayaan kepada kekuatan pelangkah, kepercayaan kepada nama-nama legenda yang semuanya bersifat gaib dan mistik. Oleh karena itu, masyarakat mempercayai sebuah jalur baru akan memenangkan pacuan jika terdapat perpaduan yang baik antara hal-hal yang bersifat fisik dan yang bersifat non fisik (gaib dan mistik).

Pembuatan sebuah jalur melalui proses yang cukup panjang dan juga memakan waktu yang lama hingga menjadi sebuah jalur dan bisa dipacukan di gelanggang. Dukun jalur merupakan tokpoh penting dalam event pacu jalur. Dengan demikian, tidak mengherankan jika pengurus jalur berupaya mencari dukun yang mempunyai kemampuan lebih dibandingkan dengan dukun lain. Peran dukun cukup besar, hal ini terlihat dari keterlibatannya mulai dari menetapkan lokasi mencari kayu, menetapkan pelangkah dalam setiap tahapan, maupun melakukan berbagai ritual yang berkaitan dengan jalur.

\section{DAFTAR PUSTAKA}

Bakri, Syaiful. (2012). "Studi Tentang Tradisi Pacu Jalur di Desa Banuaran Kecamatan kuantan Hilir Kabupaten Kuantan Singingi”. Skripsi Sarjana. Program Studi Pendidikan Luar Sekolah Jurusan ilmu Pendidikan Fakultas Keguruan dan Ilmu Pendidikan. Tidak dipublikasikan. Universitas Riau: Pekanbaru.

Hamidy, UU. (2005). Kesenian Jalur di Rantau Kuantan. Pekanbaru: Dinas Kebudayaan, Kesenian dan Pariwisata Propinsi Riau.

Hasbullah. (2014). Togak Balian: Ritual Pengobatan Tradisional Masyarakat Kenegerian Koto Rajo Kuantan Singingi. Pekanbaru: ASA Riau.

Hasbullah, Ashori, Rendi Ahmad \& AlMasri, M. Nazar. (2016). Unsur-unsur Magis dalam Tradisi Pacu Jalur. Perspektif Antropologi Agama. Sosial Budaya, 13(1), 25-44.
Hertati, H., \& Hufad, A. (2010). Fungsi dan Makna Rarak Godang Pada Acara Pacu Jalur Bagi Komunitas Melayu Di Kuantan Singingi Riau (bal. 595-600). Dipresentasikan pada The 4th International Conference on Teacher Education, Bandung.

Novrilasari, D., Saam, Zulfan \& Mulyadi, A. (2014). Strategi Pengembangan Kawasan Pacu Jalur Sebagai Waterfront City Teluk Kuantan. Pusat Penelitian Lingkungan Hidup Universitas Riau.

Piliang, Amir Yasraf. (2003). Hipersemiotika: Tafsir Cultural Studies Atas Matinya Makna. Bandung: Jalasutra.

Saleh, R. (2013). Tokoh dalam Nama-nama Jalur di Kuantan Singingi. Madab: Jurnal Babasa dan Sastra, 4(1), 48-57.

Silawati \& Aslati. (2015). Menguak Nilai-nilai Magis Pada Tradisi Pacu Jalur di Kabupaten Kuantan Singingi. Sosial Budaya, 11(2), 237-250.

Suwardi. (2007). Bahan Ajar Kebudayaan Melayu. Pekanbaru: Kampus Akademi Pariwisata Engku Puteri Hamidah.

Yulis, A. (2017). Kontribusi Event Pacu Jalur Terbadap Pertumbuban Ekonomi Masyarakat Desa Pulau Baru Kopah Teluk Kuantan Kec. Kuantan Tengah. AlAmwal: Jurnal Ekonomi Islam, 2(2), 571-605. 